seront groupés les départements de philologie, d'histoire, de philosophie, de sociologie, d'anthropologie, de pédagogie, d'économie, de droit, etc.; deux pavillons techniques pour les cliniques universitaires où seront groupés les salles d'opération, les services de radiographie, la policlinique et les services administratifs. Sont aussi en construction l'église universitaire, un seme home d'étudiants, une station agronomique expérimentale et un certain nombre de maisons.

Dans le programme de constructions prévues pour les deux ou trois prochaines années, sont prévus une faculté polytechnique, un institut agronomique, un bâtiment administratif, une bibliothèque centrale, de nouvelles cliniques, cinq homes d'étudiants, une cinquantaine de maisons de professeurs, des habitations diverses, etc.

Une haute personnalité étrangère de passage à Léopoldville disait de l'Université Lovanium qu'elle était une des réalisations les plus étonnantes qu'il lui ait été donné de visiter au cours d'un long périple en Afrique.

\title{
Fifth Meeting of the Inter-African Committee on Social Sciences
}

THE fifth meeting of the Inter-African Committee on Social Sciences was held in Brussels on 3 I March and I April I958. Among the subjects discussed were population maps, migration studies, African archives and history, archaeology and prehistory, and toponymy.

The progress made by Professor Gourou in the preparation of maps of the Belgian Congo and of Madagascar on the scale of I: 1,000,000 was welcomed. Attention was drawn to the importance of seeking international agreement to secure the greatest measure of comparability among the maps of various territories on this scale. It was therefore recommended that Professor Gourou should be invited to make proposals for the standardization of maps on the scale of $I: 1,000,000$ to be produced by all Governments with responsibilities in Africa South of the Sahara. In the meantime the Committee endorsed the recommendations of CSA and its Maps and Surveys Committee that it was also desirable that a provisional map on the scale of $r: 10,000,000$, showing distribution and density of population for Africa as a whole, should be prepared with the assistance of the Governments concerned.

The progress of research on migration studies in West Africa was noted with satisfaction, and it was recommended that when the several studies were completed a general report on the investigations should be prepared by the Joint Secretariat to be issued as a CCTA publication.

Archive resources in Africa South of the Sahara had been the subject of a two-part questionnaire. Sufficient replies had not yet been received on the official archives to make it possible to draw up a comprehensive teport. The second part of the questionnaire is to be addressed to missions, tribal authorities, and private individuals. Stress was laid on the importance of the recording of oral traditions and the teaching of the history of African peoples. A list of historians specializing in Africa is now being drawn up by the Secretariat.

The attention of Member Governments was drawn to the courses on archaeology, organized by Dr. Desmond Clark of the Rhodes-Livingstone Museum, to be held at Livingstone in July or August 1958, and also to the importance of providing in educational establishments for instruction in the archaeology of Africa. It was also recommended that archaeological studies in the area between West Africa and the Sudan, as proposed at the 1957 London Conference of African history and archaeology, should be supported by CCTA, and that the Government of the Republic of the Sudan should be invited to associate itself with the Member Governments in a joint project. Arrangements for the compilation of an atlas of prehistory, as suggested by Dr. Desmond Clark, were also discussed, and it was decided to appoint correspondents for different parts of Africa and to establish a panel of experts to examine archaeological and quartenary geological correlation. 
The Committee recommended that specialists in linguistics and ethnology should always be associated with national procedure for determining the orthography of place names on maps, and, more particularly, that these disciplines should be represented on any national or territorial toponymy committees.

Arrangements are now being made for a CCTA/CIE Symposium on Child Welfare in West Africa in February 1959. It is hoped to hold the next meeting of the Committee in Lisbon early in 1959 .

\section{International Institute of Differing Civilizations}

THe International Institute of Differing Civilizations will hold its 3 rst session in Brussels from 17 to 20 September 1958 , under the Presidency of M. Henri Depage. The subject discussed will be "The Role of Women in the Development of Tropical and Sub-Tropical Countries '. The subject will be examined in its legal, social and cultural, economic, and political aspects, each of which will be discussed in a general report. Some twenty special reports, dealing with the position in particular territories or regions, will be circulated beforehand so that participants may have the opportunity to study them closely in advance. After the opening session, discussion will begin immediately on the basis of questions at the end of their papers presented by the writers of the general reports. At the close of the debates conclusions will be adopted which will form a synthesis of the views put forward and will bring out their main trends. All the discussions will be carried out at plenary meetings. An editorial board consisting of the writers of the general reports will draft the conclusions.

\section{International Journal of Health Education}

THE first number of the official quarterly journal of the International Union for Health Education of the Public appeared in January. It contains a short account of the first African Seminar on Health Education of the Public which was held in Dakar from 25 to 30 March 1957, under the auspices of WHO in collaboration with the French Government. Dr. Louis Sanner, Director General of Public Health in French West Africa, also comments on this seminar in an article 'Striding ahead in Africa'.

\section{Ford Foundation-African Studies Fellowship Program}

THE Foundation has awarded the following grants for field research in $2958-9$ :

Norman R. Bennett (Boston): Islamic penetration of East Africa in the late nineteenth and early twentieth centuries (England, Zanzibar, and East African coastal areas).

Philip D. Curtin (Wisconsin): ' Native policy' in British West Africa during the nineteenth century (London, Sierra Leone, Ghana, and Nigeria).

Nicholas M. England (Harvard): Bushmen cultures in the Kalahari Desert, Southwest Africa, Bechuanaland, and Union of South Africa.

William H. Friedland (Berkeley, California): Process of industrialization and trade union development in Northern Rhodesia (Boston, England, and Northern Rhodesia).

Peter $R$. Gould (Northwestern): Transportation as a factor in the economic development of Ghana (Ghana).

John $R$. Howard (Northwestern): Personality variation in an Ibo village (Nigeria).

Gail M. Kelly (Chicago): An African dialect, and the effect of Western cultural traditions on Ghana.

Herbert S. Lewis (Columbia): Ethnographic study of the native kingdoms in southwest Ethiopia. 